\title{
A systematic literature review regarding the influence of lean manufacturing on firms' financial performance
}

\author{
Marcos Dieste \\ Department of Management and Engineering, University of Padova, \\ Vicenza, Italy and \\ Faculty of Science and Technology, Free University of Bozen-Bolzano, \\ Bolzano, Italy \\ Roberto Panizzolo \\ Department of Management and Engineering, University of Padova, \\ Vicenza, Italy, and \\ Jose Arturo Garza-Reyes \\ Centre for Supply Chain Improvement, The University of Derby, \\ Derby, UK
}

\begin{abstract}
Purpose - The lean philosophy has demonstrated its effectiveness to improve firms' operational performance. However, the impact of lean practices on financial performance is still unclear due to the poor understanding of the link between operational and financial measures and the conflictive results obtained by previous research. The purpose of this paper is to conduct a systematic literature review to understand whether lean companies have improved their financial performance. Moreover, this article aims to uncover research gaps in the literature and examine which time spans of research have been considered to analyse both the degree of lean implementation and the measurement of financial outcomes.

Design/methodology/approach - A systematic literature review has been conducted to identify peerreviewed articles that analyse the effect of the lean production paradigm on the financial performance measures of manufacturing companies. Then, the identified articles were processed using a combination of descriptive and content analyses methods to draw new conclusions, uncover gaps and find novel paths for research.

Findings - Various authors indicate that lean initiatives lead to an enhancement of financial performance measures. JIT and TQM lean practice bundles are suggested as the best enablers of financial performance in terms of sales and profit. In contrast, according to some scholars, lean does not necessarily improve companies' financial results if it is not properly implemented.

Originality/value - Several studies have focused on analysing the effects of lean on performance. However, only a small part of the literature has addressed the study of the effects of lean practices on financial performance metrics. The originality of this study lies in the investigation of the connections between lean practices and financial performance measures found in the literature. The outcome is the identification of various possible positive impacts of some lean practices on financial metrics.
\end{abstract}

Keywords Lean manufacturing, Practices, Measures, Financial performance, Business performance,

Competitiveness

Paper type Literature review

(C) Marcos Dieste, Roberto Panizzolo and Jose Arturo Garza-Reyes. Published by Emerald Publishing Limited. This article is published under the Creative Commons Attribution (CC BY 4.0) licence. Anyone may reproduce, distribute, translate and create derivative works of this article (for both commercial and non-commercial purposes), subject to full attribution to the original publication and authors. The full terms of this licence may be seen at http://creativecommons.org/licences/by/4.0/legalcode

This work was supported by the Veneto Region (Italy) [FSE/DGR n. 204-26/02/2019, Project code 6813-0001-204-2019].
Received 6 August 2020 Revised 29 October 2020 20 January 2021

Accepted 9 March 2021 
JMTM 32,9

102

\section{Introduction}

Under the leadership of Taiichi Ohno, Toyota defined a new industrial production model focused on the reduction of waste, continuous improvement and the importance of involving all company employees (Ohno, 1988). In their book, Womack et al. (1990) define lean in terms of its outcomes: "compared to mass production it uses less of everything - half the human effort in the factory, half the manufacturing space, half the investment in tools, half the engineering hours to develop a new product in half the time".

During the last decades, the lean thinking theory has been evolving. Both researchers and practitioners have stressed the importance of extending the principles of lean production to other company areas (Womack and Jones, 1996). Several industrial firms worldwide have put into practice both lean principles and practices and have achieved important transformations towards continuous improvement, value creation and waste elimination, accomplishing outstanding operational efficiency levels.

In the academic field, numerous authors have studied the aforementioned empirical evidence and have suggested that lean manufacturing initiatives improve companies' operational performance (Demeter and Matyusz, 2011; Shah and Ward, 2003). The links between lean and operational measures have been deeply studied since it is obvious that the direct impact of lean practices is reflected in production processes' performance metrics or operational performance metrics (Negrão et al., 2017).

Nevertheless, financial performance measures are those that reflect the performance of the whole company in terms of economic indicators and portray the ability of firms to create value (Galeazzo and Furlan, 2018). These performance measures are directly related with operational performance (Fullerton et al, 2014), but according to some authors, the link between both dimensions may be fragile (Bhasin, 2012; Losonci and Demeter, 2013) as nonfinancial measures are not part of traditional accounting systems (Abdel-Maksoud et al., 2005). This suggests that financial performance measures could be more consequential than operational performance measures given the levels of lean maturity in current production environments.

The first studies on this topic have investigated the effect of different dimensions of the lean production system such as just in time (JIT) or total quality management (TQM) on financial performance (Callen et al, 2000; Eriksson and Hansson, 2003). These practices are part but not synonymous of lean production (Hofer et al., 2012). According to some authors, lean production is more than a technique; it is a holistic system approach that creates a culture in which everyone in the organization continuously improves operations (Liker, 2004; Sahoo and Yadav, 2018). In order to study in a more holistic approach the effects of lean practices on financial performance, authors have included the other two dimensions of the lean paradigm, namely total preventive maintenance (TPM) and human resource management (HRM), applying the important work developed by Shah and Ward (2003). According to these authors, lean practices with similar characteristics can be classified into four groups or "lean bundles" (i.e. JIT, TQM, TPM and HRM). The bundle model has been widely used by academics for the study of the impact of lean on financial performance.

Prior research suggests that lean practices have a positive effect on financial performance metrics (Sahoo, 2019; Yang et al, 2011), and, moreover, various studies remark the importance of implementing lean practices as a whole (Fullerton et al., 2014) and in a structured manner (Nawanir et al, 2013) to achieve better financial performance results. In contrast, some scholars do not fully agree with this evidence and suggest that the positive links between lean and financial performance are not so obvious and may depend, among others, on external (Losonci and Demeter, 2013) and internal factors to the company (Bevilacqua et al, 2017a).

The purpose of this study is to develop a systematic literature review regarding the effect of lean practices' implementation on financial performance measures. Additionally, research gaps in the literature and future research directions are also identified. For this aim, a deep 
analysis of the most used lean practices and the financial indicators measured in previous research will be carried out. Subsequently, the relationships found in the literature will be depicted to understand whether firms that have applied lean practices have improved their financial performance measures and which lean practices best benefit financial performance metrics. In addition, the possible negative effects on financial performance derived from the implementation of lean initiatives already identified in literature will be described. Considering this, the main research questions addressed in the literature review are:

(1) What are the results obtained by previous research regarding the effects of lean on financial performance?

(2) What is the connection between lean and financial performance measures?

(3) What are the main paths for further research when concurrently investigating lean and financial performance?

The originality of this study lies in the investigation of the connections between lean practices and financial performance measures found in literature, resulting in the identification of various possible positive impacts of each practice on each indicator. In contrast, various relevant inconsistencies exposed in the literature are provided. Furthermore, understanding which time intervals have been considered for the analysis of the implementation of lean practices is strongly significant. It is also important to recognize how many years have been considered in previous research for measuring financial performance. This will allow researchers to identify which of the prior studies could be anecdotal and which are based on sustained data over time. In this regard, this paper provides relevant insights for both practitioners and scholars, remarking the importance of a long-term implementation and analysis of lean practices. These contributions facilitate the general understanding of the specific effects of lean practices on each financial performance measure so far investigated in the literature, regrouping them and giving them a numerical value to emphasize their importance. Finally, research gaps and future research recommendations are stressed in the form of research questions to enrich the study of the effects of lean practices on financial performance measures.

\section{Research method}

A systematic literature review has been conducted to identify peer-reviewed articles that aimed to analyse the effect of the lean production paradigm and its practices on the financial performance measures of manufacturing companies. The systematic literature review (SLR) method approaches in a precise, transparent and explicit manner the analysis of scientific research documents. This method, which includes various phases, guarantees rigour and comprehensibility to the literature review process (Tranfield et al., 2003) due to the systematic, explicit and reproducible approach adopted (Fink, 2005). Several academics consider that systematic literature reviews should include the following five sequential stages (Buchanan and Bryman, 2009): scope formulation, study location, study evaluation, analysis and synthesis, and reporting and using the results (see Figure 1). For reasons of transparency, these sequential phases and the methods used to support every stage will be explained in detail throughout the paper (Saunders et al., 2009).

Following this paragraph, in Section 2.1, together with the premises introduced in Section 1, the scope of the research is formulated corresponding to the first phase of the systematic literature review. Then the following stages of the literature review are successively presented in the next sections of this paper.

\subsection{Scope formulation}

The recent attention paid in previous research to the relationship between lean and both operational and financial performances has encouraged authors to explore its implications in 
JMTM 32,9

\section{4}

Figure 1 .

SLR phases and structure of the paper

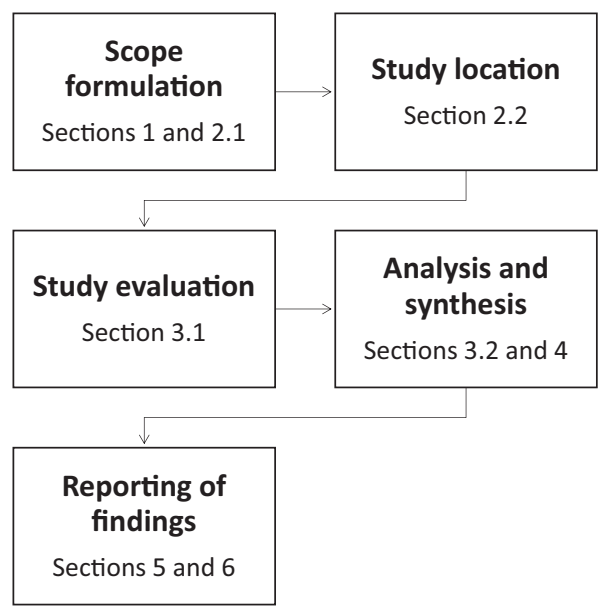

different dimensions (Dieste et al., 2019). An increased emphasis has been put in previous studies regarding the analysis of the implications of lean production on operational performance (Negrão et al., 2017), and, moreover, several authors suggest that there is a direct positive effect of lean on operational performance measures (Chavez et al., 2013; Cua et al., 2001; Shah and Ward, 2003; Shrafat and Ismail, 2019).

Lean manufacturing, which is frequently implemented at a shop-floor level, is naturally associated with production processes and therefore involves the use of non-financial measures which are not part of traditional accounting systems (Abdel-Maksoud et al., 2005). This suggests that lean companies may be more likely to use non-financial measures for measuring performance rather than financial performance metrics (Nawanir et al., 2013). The link between lean practices and non-financial metrics is easier to identify than the effects of lean on financial performance measures. Nevertheless, operational performance subsequently influences the entire business performance. In order to observe the ability of a lean organization to create value, it is more appropriate to understand the effects of lean production on financial performance (Galeazzo and Furlan, 2018).

Previous studies have already approached the topic and demonstrated that lean implementation may have a positive impact on financial measures of manufacturing organizations (Fullerton and Wempe, 2009; Hofer et al., 2012; Negrão et al., 2019), and, moreover, researchers suggest that to reach its potential, lean must be adopted as a holistic business strategy, instead of single isolated activities in operations (Fullerton et al., 2014). However, as suggested by Bhasin (2012), the lean benefits on financial performance are not always obvious since the connection between financial and non-financial measures is fragile. Some other authors have already explored this issue and have confirmed that the financial benefits derived from the lean implementation are not always tangible (Ghobakhloo and Azar, 2018; Losonci and Demeter, 2013). Moreover, some scholars suggest that lean may produce a negative impact on financial metrics due to inadequate implementation of the lean bundles (JIT, TQM, TPM and HRM) (Galeazzo and Furlan, 2018), to the lack of a systematic and sustainable approach (Bevilacqua et al., 2017a) or to the use of ineffective financial reporting methods (Meade et al., 2010).

In summary, various authors have already approached the impact of lean production on the financial performance of manufacturing companies. However, the academic literature exploring this research topic still needs further investigation, since the impact of lean on financial measures is still unclear due to the conflictive results already obtained by previous 
research. Therefore, this article provides a comprehensive literature review on the current state of the research on this relevant subject, aiming to give light on the effects of the lean philosophy on financial results, uncover gaps and inconsistencies in the literature and find new research directions.

\subsection{Paper selection method}

To identify the most relevant research papers for this literature review, the Scopus search database was selected since it provides extensive coverage of peer-reviewed journal articles in the scientific, technical and social sciences research fields. This SLR considered peerreviewed articles published in the English language without limiting the search to a specific period. All fields of knowledge, as well as all subject areas available in the Scopus database, were selected.

The selected keywords were used in the title, abstract and keyword search fields using the following Boolean operators: lean AND manufacturing AND (financial OR performance). More specifically, the keyword "lean" was selected to include concepts such as "lean thinking" or "lean production"; subsequently, the keyword "manufacturing" was chosen to incorporate as far as possible studies developed within the manufacturing sector. Finally, both keywords "financial" and "performance" were selected. The first aims to address all papers investigating specifically financial measures. The keyword "performance", which has a broader meaning, was included to identify all the articles that study the relationship between lean and performance (operational, financial and environmental), enabling this way later filtering of the articles and not losing information.

As seen in Table 1, a total of 2,303 papers were initially found using the keywords search in the Scopus database. Thirty-one papers were not written in the English language, and thus the total number of articles listed was 2,272. By excluding reviews, conference papers, book chapters and other document types, 1,221 papers were identified. Considering only papers that fit with fields of knowledge such as engineering, management, social sciences or similar, 1,119 papers remained in the selection protocol. Then, only papers addressing issues of lean and performance measurement, evaluation or assessment were selected. Papers addressing the adoption of single practices or bundles (e.g. standalone implementation of JIT or TQM) and joint applications such as lean six sigma, lean-green or supply chain analyses were rejected, resulting in a total of 141 articles. Then, all abstracts were read, and 100 papers were

\begin{tabular}{llc} 
Criteria & Description & $\begin{array}{c}\text { Total number of papers } \\
\text { remaining }\end{array}$ \\
\hline Keyword search & $\begin{array}{l}\text { Articles must contain the keywords searched in the } \\
\text { title, abstract or keywords }\end{array}$ & 2,303 \\
$\begin{array}{l}\text { Language exclusion } \\
\text { Source-type exclusion }\end{array}$ & $\begin{array}{l}\text { Onlection of articles written in English } \\
\text { Field of knowledge }\end{array}$ & Papers that match the field of knowledge \\
exclusion & Only articles that strictly fit the lean and performance & 2,272 \\
Topic of interest & research topic & 1,221 \\
exclusion & Relevant studies were selected after the abstract & 1,119 \\
Abstract reading & reading process \\
exclusion & Only papers including financial measures were & 141 \\
Full paper reading & selected \\
exclusion & Two relevant papers were added during the full paper \\
Snowballing inclusion & reading exclusion & 41 \\
Final paper selection & & 22 \\
\end{tabular}

Total number of papers

2,272

1,221
Lean and financial performance: a review 
JMTM 32,9

106

excluded for lack of relevance to the study or for not having a comprehensive approach. From the 41 papers remaining, 19 were excluded after full-text reading, as these papers did not analyse any financial performance measures. During the reading process of the 22 remaining articles, the studies developed by Lewis (2000) and Hofer et al. (2012), which have been considered by various authors from the list (Bevilacqua et al., 2017b; Negrão et al., 2017; Sahoo and Yadav, 2018), were not included in the initial sample and therefore were added. Both papers belong to the topic of interest of this study: Lewis (2000) studied financial performance while examining the sustainable competitive advantage of manufacturing firms; Hofer et al. (2012) investigated the relationship between lean production and performance but did not use the keyword "manufacturing" even though the empirical analysis developed is based on data from the US manufacturing firms. To avoid losing any other relevant articles, a final check was made of the references cited by the 24 papers already included in the sample. It was then found that there were no missing articles within the final paper selection. Finally, 24 papers over the period of 2000-2019 were identified and selected for the analysis.

The selection process developed and the final number of papers selected confirm that despite the great number of studies analysing the effects of lean on performance, only a small minority address properly the effects of lean practices on financial performance measures. Most of the studies are focused on the relationship between lean, lean six sigma or lean supply chain management practices and operational performance. As was stated before, the relationship between lean and operational performance has been deeply studied in literature as the effects of lean on operational measures are more noticeable rather than the impacts of lean on financial performance.

\section{Literature review analysis}

\subsection{Descriptive analysis}

A total number of 24 articles (Appendix) complied with the final selection criteria. Hence, these were all the articles that, to a certain extent, referred to lean and financial performance in operations management literature. The selected papers have been categorized according to various criteria: publication date, source of publication and research method used.

The first classification is presented in Figure 2, which shows the sorting of the selected articles according to their publication date. To ensure greater clarity, the papers were grouped in five-year intervals starting from 2000 until 2019. The graph highlights the growing significance given in the literature to the study of the relationship between lean and financial performance, from 2010 onwards and particularly in the last 5 years.

Figure 2.

Article classification by year of publication

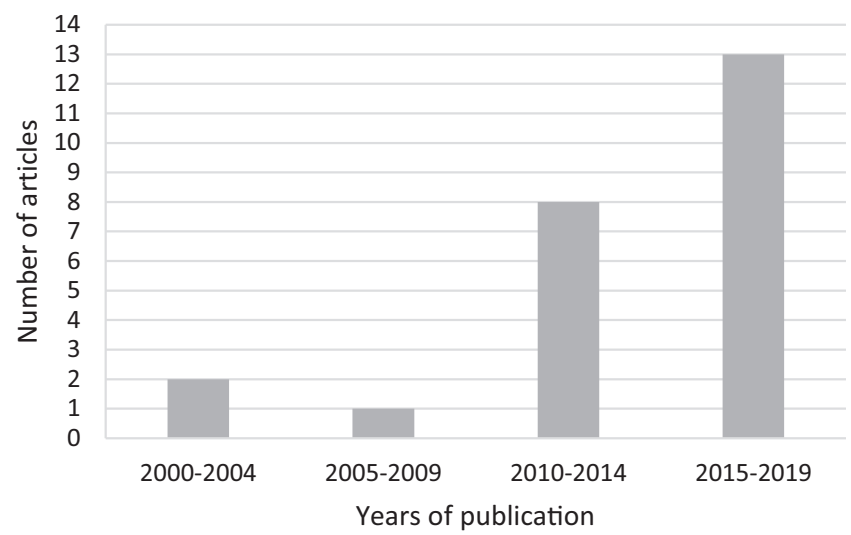


Figure 3 shows the distribution of the selected papers by journal type. In terms of the number of publications per source, the Journal of Manufacturing Technology Management with $25 \%$ ( 6 articles) of the total number of lean-financial performance publications analysed, is the most repeated source of publication. Secondly, both the International Journal of Operations and Production Management and the International Journal of Production Economics contribute $12.5 \%$ each (3 articles each). These are followed by 3 journals with strong significance in the operations management field, with 2 publications each. The rest of the articles are subdivided in 6 different journals of high impact with one publication each.

The complete set of papers has been categorized in Figure 4 according to the research methodologies adopted.

As shown in Figure 4, 18 articles (75\% of the total) investigated the topic through a survey-based methodology. Various survey studies employed a structural equation modelling (SEM) approach to test the theoretical relations (Bevilacqua et al., 2017a; Chavez et al., 2015; Fullerton et al., 2014; Shrafat and Ismail, 2019). Other papers mainly used statistical methods such as regression analysis to process the survey data (Forrester et al., 2010; Galeazzo, 2019; Sahoo and Yadav, 2018). Studies such as Hofer et al. (2012) and Fullerton and Wempe (2009) analysed a combination of survey and secondary data to empirically investigate the relationship between lean production implementation and financial performance. Bhasin (2012) used a combination of primary data captured from 68 survey questionnaires and 7 case studies to validate research findings.

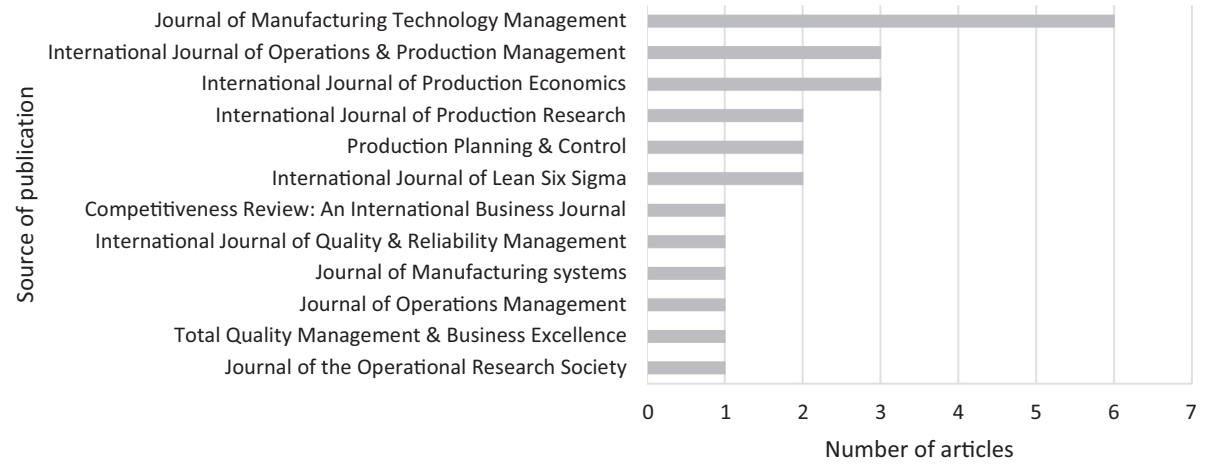

Figure 3

Article classification by source of publication

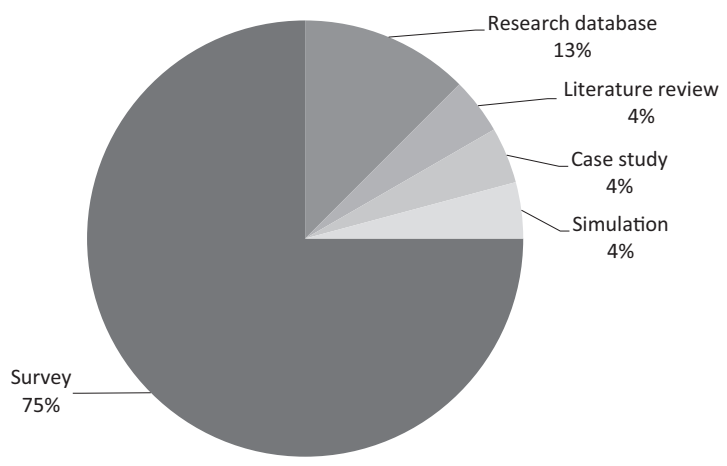

Figure 4.

Article classification by research method adopted 
JMTM 32,9

108

To a lesser extent, $13 \%$ of the studies (3 articles) analysed secondary data from a database. Both studies developed by Losonci and Demeter (2013) and Yang et al. (2011) used the International Manufacturing Strategy Survey (IMSS IV) data bank for their statistical analyses. This database contains 711 observations developed between February 2005 and March 2006 collected from 23 countries. In addition, Zhu and Lin (2017) developed an empirical analysis of Chinese manufacturing firms using data from the China Stock Market and Accounting Research (CSMAR) database and CNINFO information to understand if lean manufacturing adoption improves firm value.

Only one article from the final paper selection developed a literature review. The research conducted by Negrão et al. (2017) analyses 83 papers published until 2015. Authors examine articles that evaluate the degree of adoption of lean manufacturing practices and the links between them and operational, financial and environmental performance measures. Lewis (2000) analysed the empirical evidence drawn from three case studies to argue whether lean production can reinforce competitive advantage and improve firms' overall financial performance. Finally, Meade et al. (2010) studied the impact of lean manufacturing adoption on net profit utilising a multi-period simulation technique. In summary, these last three articles that approached the topic with three different methodologies represented $12 \%$ of the paper sample.

\subsection{Content analysis}

3.2.1 Lean practices in literature. The purpose of this section is to understand which lean practices or groups/bundles of lean practices are the most used in the sample of 23 manuscripts under analysis. The literature review paper was excluded from this analysis since it gathers previous results from other studies. Therefore, 47 different lean practices were found in the whole literature sample. Due to their relevance, the ten most used lean practices and bundles are listed in Figure 5 in descending order of citations. Both lean bundles and practices were included in the figure to emphasize whether scholars utilized single practices to study the effect of lean on financial performance or they preferred to gather them into groups of practices. It is worth noting that only lean practices that were quoted at least 6 times in the reviewed studies were included in the graph.

Figure 5.

Lean practices most frequently studied

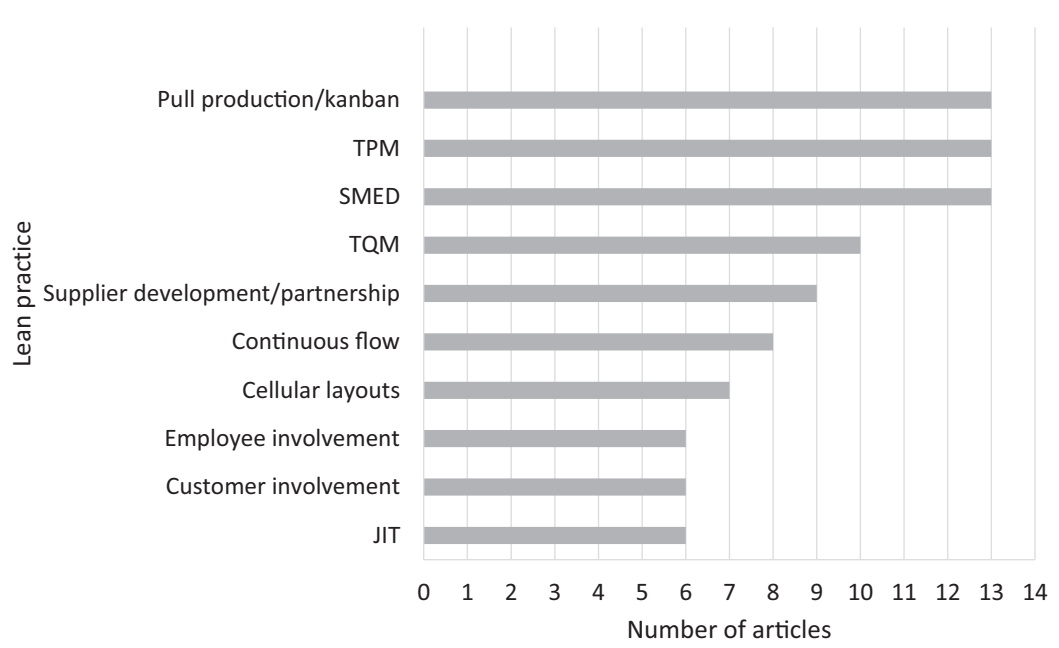


As stated above, various authors do not refer to single lean practices but to groups of lean tools: these are the well-known lean bundles developed by Shah and Ward (2003). For this reason, it is possible to identify TPM and TQM as two of the most important lean techniques for the analysis of the effects of lean on financial performance. However, a deeper analysis allows identifying 5 out of 10 practices that match with the JIT lean bundle. These practices are pull/Kanban, SMED, continuous flow, cellular layouts and JIT, and authors such as Bhasin (2012), Fullerton et al. (2014) and Nawanir et al. (2016) employed most of them in their empirical analyses. Hence, practices belonging to the JIT bundle seem to be the most frequently analysed by researchers in the field (see Figure 5).

Furthermore, practices included in both TQM and TPM bundles have been studied by many authors (Galeazzo, 2019; Ghobakhloo and Azar, 2018; Sahoo and Yadav, 2018). In contrast, except for the employee involvement practice, which is ranked within the most utilized practices (Bevilacqua et al., 2017a; Hofer et al., 2012), HRM practices seem to receive less attention in the literature. This may occur because the "soft" part of lean (which is related to behavioural and social aspects) sometimes does not receive equal importance from companies than more technical lean tools, and therefore this is reflected in the results of previous research (Sahoo, 2019).

3.2.2 Financial performance measures in literature. In this section, the attention is focused on the financial performance measures considered in the existing literature when analysing the relationships between lean implementation and financial performance of manufacturing firms.

Within the sample of 23 papers analysed (excluding the literature review article), a total number of 32 different financial/business performance metrics were found. In Figure 6, the ten most used financial measures are listed in descending order of citations.

According to Figure 6, the most used financial performance measure within the selected papers is the return on investment ratio (ROI). Out of 23 studies, 7 used this ratio to measure the degree of achievement of profit-oriented outcomes (Hofer et al., 2012; Yang et al., 2011). This measure, according to Nawanir et al. (2016), shows how the firm's assets have been used to make earnings, thus showing how proficient management is.

Secondly, 6 out of the 23 articles used the sales growth rate. This indicator is utilized to show how firms are performing in the market (Bevilacqua et al., 2017a; Chavez et al., 2015).

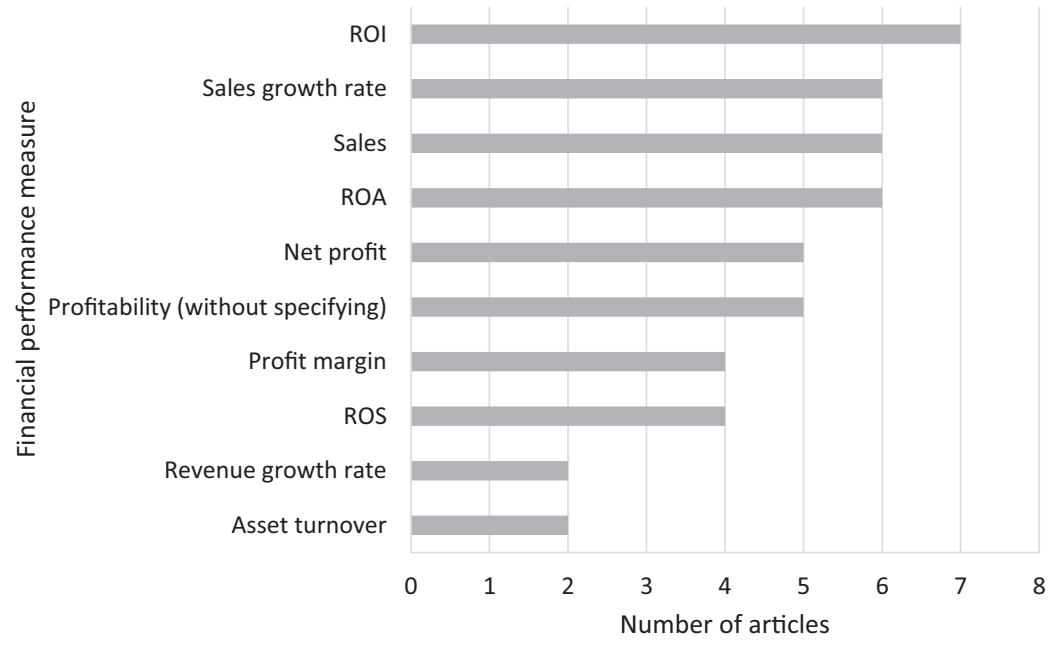

Figure 6.

Financial measures most frequently studied 
JMTM 32,9

Similarly, the absolute level of sales was utilized by 6 articles in order to assess market (Yang et al., 2011) and financial performance (Lewis, 2000; Negrão et al., 2019). Again, 6 articles used the return on assets ratio (ROA) to evaluate firms' efficiency improvements from a financial point of view (Fullerton et al., 2014; Zhu and Lin, 2017).

Thirdly, 2 measures were studied each by 5 papers out of the 23 under analysis. The level of net profit, together with other performance measures, was used by Sahoo (2019) to evaluate the strategic business performance of both soft and hard lean practices. Similarly, the profitability indicator was used by 5 articles. It is noteworthy that these studies did not indicate which specific ratio was used for its calculation in each company. The level of profitability of a firm can be calculated by several ratios considering its financial statements: for instance, Shrafat and Ismail (2019) measured it to evaluate one of the three dimensions of business performance (profitability, market share and customer satisfaction).

To a lesser extent, 4 out of 23 articles used profit margin as a financial performance measure (Bevilacqua et al., 2017b; Chavez et al., 2015; Nawanir et al., 2013, 2016). The same number of papers studied the return on sales ratio (ROS) since it is a widely accepted measure of profitability (Hofer et al., 2012) and eliminates some of the effects of reduced inventories in the arising of the ROA ratio (Fullerton and Wempe, 2009). Finally, both revenue growth rate and asset turnover were considered each by 2 papers out of 23 .

3.2.3 Time spans of analysis in literature. In previous sections, both lean practices and financial measures have been analysed separately according to their presence in literature. Besides, understanding which periods have been considered for the analysis of the implementation of lean practices is strongly significant. Generally, the time during which a company has been implementing lean principles and the extent of the implementation is known as lean maturity. Additionally, it is highly important to summarize how many years have been considered to analyse the financial performance of firms in previous studies. Both topics are crucial to find out which of the previous studies could be anecdotal and which were based on sustained data.

This section presents the time spans selected by each of the 23 papers (excluding the literature review) and describes how authors analysed both lean implementation and financial performance results.

First, 15 out of 23 papers did not consider any period of implementation of lean practices. Most authors relied on cross-sectional survey-based studies (e.g. Fullerton and Wempe, 2009; Ghobakhloo and Azar, 2018; Sahoo, 2019), evaluating lean practices' degree of implementation using Likert scales in the research questionnaires. In contrast, Bhasin (2012) only considered the number of years of lean practices' implementation at the time the survey was conducted by requesting it in the research questionnaire. Similarly, various scholars, in addition to the information about the years of lean implementation experience, requested a Likert scale evaluation of the degree of leanness (Galeazzo and Furlan, 2018; Sahoo and Yadav, 2018) or to assess whether a lean practice has been implemented in the company or not (Galeazzo, 2019). Other authors (4 out of 23 papers) evaluated jointly the degree of implementation and years of implementation of each practice using a Likert scale (Bevilacqua et al., 2017a, b; Yang et al., 2011) or by semi-structured interviews (Lewis, 2000).

Secondly, 8 out of 23 of the papers did not consider a specific period for evaluating the variation of financial metrics. These studies generally used a Likert scale to analyse the evolution of companies' financial measures either alone (e.g. Negrão et al., 2019; Shrafat and Ismail, 2019) or compared to their main competitors (Chavez et al., 2015; Ghobakhloo and Azar, 2018). The rest of the articles studied the relationship between lean practices and financial measures considering different time spans of research. For instance, various authors analysed performance changes over three-year periods by rating their variation using a Likert scale (Nawanir et al., 2013; Yusuf and Adeleye, 2002); others used a database for 
extracting the indicators of the last three years (Forrester et al., 2010) or for obtaining financial measures in three different points in time (Galeazzo and Furlan, 2018). In total, 9 out of 23 papers used a time span of three years.

In addition, Zhu and Lin (2017) considered a longer period of time and extracted firms' financial measures over five years from a database to analyse performance changes. Galeazzo (2019) used also a database to investigate performance changes over at least a two-year period. Bevilacqua et al. (2017a) and Meade et al. (2010) developed shorter analyses; the first study evaluated a time span of two years using a Likert scale in the survey questionnaire, while the second research used a single year period generating values with a simulation method. Lewis (2000) obtained data from the financial reports of the case firms under analysis at two different points in time: immediately before lean transformation and five years later as part of the qualitative analysis developed.

Finally, Bhasin (2012) requested the respondents of a survey to quote a percentage improvement or deterioration against each index as a direct consequence of the lean transformation. This was achieved by providing a scorecard within the survey containing the financial metrics under analysis and asking interviewees the time since lean production has been implemented.

\section{The effect of lean practices on financial performance measures in literature}

As a final analysis, this section describes the effects of lean practices on financial performance metrics found in the selected studies. For this purpose, the positive, mixed and negative results observed are acknowledged in the following paragraphs.

\subsection{Positive effects of lean practices on financial performance measures}

From the analyses carried in Sections 3.2.1 and 3.2.2, it turned out that 47 lean practices and 32 financial performance measures were used in the studies considered. A first analysis of the papers after the full-text reading process permitted to conclude that many articles highlight a positive impact of lean practices on financial measures. Among the 23 papers, several lean practices with similar characteristics have been evaluated with a huge number of financial performance metrics, and some of these practices and metrics have the same scope but a different nomenclature.

Thus, in order to solve this problem and to improve the clarity and relevance of the results, those lean practices that positively impact financial measures have been categorized with the bundle model developed by Shah and Ward (2003), which has also been used and adapted by some of the papers under analysis, for example, Bevilacqua et al. (2017a), Galeazzo and Furlan (2018) or Sahoo and Yadav (2018):

(1) The JIT bundle includes practices such as pull/Kanban, small lots of production, SMED, continuous flow production and cellular layouts.

(2) The TQM bundle gathers lean practices like kaizen, customer involvement, visual management, statistical process control and $5 \mathrm{~S}$.

(3) The TPM bundle contains practices related to preventive and autonomous maintenance

(4) The last bundle, known as HRM, includes practices such as multiskilled workforce, employee involvement and lean leadership.

Similarly, those performance metrics which were positively impacted by certain lean practices have been grouped in bigger categories according to their scope. Therefore, the most relevant resulting categories were ROI, sales, ROA and profit: 
JMTM 32,9

112

(1) The ROI category includes the ROI ratio and ROI growth rate.

(2) The sales group gathers metrics such as sales, net sales, ROS and sales growth rate.

(3) The ROA category encompasses the ROA ratio and ROA growth rate.

(4) The profit group includes measures of profitability, profit margin and net profit.

Table 2 illustrates the positive relationships found in the literature between the lean practice bundles and the financial performance categories. The value inside the cells shows the number of times a positive relationship has been found in the literature between the bundle in the row and the financial performance category of the column. In addition, the rightmost column in Table 2 shows the degree of importance of each lean bundle according to its positive effect on financial performance. Similarly, the last row indicates the financial categories that benefit the most from the implementation of lean practices according to extant literature. Nevertheless, it must be emphasized that not all the relationships found in the literature were positive. Some scholars suggest that lean does not necessarily improve firms' financial results, and, moreover, various authors state that lean may have negative impacts on financial performance metrics. This evidence is analysed in Section 4.2.

The results shown in Table 2 suggest that the JIT bundle, with techniques related to production flow, could have a positive influence on the measures corresponding to sales and profit. For instance, Chavez et al. (2015) suggest that internal lean practices such as setup time reduction techniques (SMED) or pull production systems are positively associated with organizational performance metrics related to sales or profit. Negrão et al. (2019) added that some practices like continuous flow practices should be prioritized, rather than other practices to help firms produce positive effects on sales and profitability. Likewise, but with less relevance in the literature analysed, a comprehensive implementation of lean practices including cellular layouts and small lots production may entail an improvement on business performance metrics such as ROI (Nawanir et al., 2016). Authors such as Fullerton et al. (2014) suggested that a holistic implementation of lean practices including Kanban and one-piece flow contributed to the improvement of the ROA ratio.

Secondly, according to some scholars, TQM practices such as continuous improvement (or kaizen), 5S, customer involvement and statistical process control uncover and eliminate hidden wastes, inefficient processes and could enhance business performance parameters. Even soft lean practices included in this bundle such as customer involvement and supplier development and partnership contributed in some studies to the improvement of sales performance measures (Sahoo, 2019). Besides, Shrafat and Ismail (2019) indicated that techniques such as statistical process control and $5 \mathrm{~S}$ contributed to the profitability enhancement of the Jordanian companies investigated. Less evidence of a positive relationship between TQM practices and ROI and ROA ratios was found, and one of these studies was developed by Sahoo and Yadav (2018).

Besides, the literature suggests that HRM practices such as employee involvement are critical to the successful adoption of lean production, and this improvement initiative has varied positive impacts on the ROS metric (Fullerton and Wempe, 2009). In addition, profit

\begin{tabular}{llrrrrr} 
& & ROI & Sales & ROA & Profit & Bundle's degree of importance \\
\cline { 2 - 6 } Table 2. & JIT & 15 & 45 & 12 & 44 & 116 \\
Summary of the & TQM & 10 & 38 & 10 & 28 & 86 \\
positive effects of lean & TPM & 3 & 8 & 3 & 9 & 23 \\
on financial & HRM & 3 & 11 & 3 & 7 & 24 \\
performance measures & Most impacted financial category & 31 & 102 & 28 & 88 & \\
\hline
\end{tabular}


measures might be improved using other soft lean practices such as flexible human resources as was remarked by Nawanir et al. $(2013,2016)$.

To a lesser extent, various studies have also indicated that TPM practices in a lean implementation context can contribute to enhancing financial performance measures. Literature has demonstrated the positive impact of this lean bundle, although with less emphasis, on measures such as profitability (Bhasin, 2012), sales (Hofer et al., 2012), ROI (Sahoo and Yadav, 2018) and ROA (Galeazzo and Furlan, 2018).

As a final point, it is noteworthy that the figures in Table 2 are not identical to the figures included in Figures 5 and 6. The reason is that in this table, only positive relationships present in the literature are analysed. For instance, if a paper suggests that two different practices produce improvements in one single performance measure in the same study, in this chart the article will be considered twice as it represents both effects of two practices in one performance measure. Furthermore, not all lean practices ( 47 practices) impacted positively on all financial metrics found in the literature sample (32 metrics), and therefore a lower number of practices and measures were used to compose the bundles-groups included in Table 2.

\subsection{Other effects of lean practices on financial performance measures}

As previously stated, the results achieved to date seem to be encouraging towards the implementation of lean practices and principles to improve different dimensions of financial performance. However, eight studies suggest that lean does not necessarily improve companies' financial results.

By comparing firms with a high degree of application of lean practices and low lean implementers, Bevilacqua et al. (2017b) highlighted that there were no major differences between high lean performers and low lean performers in terms of business growth (i.e. profit margin) when firms vary the batch size, reduce production time, reduce the percentage of finished products which are subject to claim and increase investment in research and development.

Losonci and Demeter (2013) conclude that despite the strong positive link between lean production and good operational performance, financial and market benefits derived from lean implementation are not obvious in terms of sales, ROS and ROI. This occurs due to the influence of external factors such as market dynamics, new entrants and customization.

Similar conclusions were obtained previously by Lewis (2000) in his qualitative exploratory study. The paper discusses the impact that lean has had on the overall financial performance, with empirical material drawn from three case studies. Research findings confirm that becoming lean does not automatically result in improved financial performance in terms of gross profit and sales. Moreover, the study remarks that the main issue seems to be the company's ability to appropriate the value generated by any savings the firm can make. In fact, the organizations under analysis obtained very different results, and, moreover, the firm with less progress towards lean production achieved the best financial results.

Furthermore, authors such as Ghobakhloo and Azar (2018) suggest agile manufacturing as an enabler of marketing and financial performance (i.e. ROA, ROI and sales growth rate) as an alternative to lean manufacturing, which is primarily associated with operational performance. Among the main reasons for these results, authors remark the importance of both costs and benefits of the lean transformation. For instance, firms have to bear the costs of dismantling previous physical plant layouts or training employees. Therefore, as there are many potential costs and indirect benefits associated with lean implementation, its ability to increase financial results might be unclear.

These results are in line with the conclusions obtained previously by Yusuf and Adeleye (2002). By comparing both lean and agile strategies in the UK context, authors concluded that 
JMTM 32,9

114

the lean companies scored highly on cost and quality. These results turned out to have a limited relationship with financial metrics such as sales and net profit. Thus, the authors suggested adopting agile manufacturing strategies instead of lean strategies, since agile companies performed better.

Bevilacqua et al. (2017a) reject a direct relationship between lean practice bundles implementation and company growth performance (i.e. sales growth rate). Authors stress that the lack of a systematic and sustainable approach, such as value stream mapping, may lead to a misapplication of lean manufacturing tools. Moreover, the lack of employees' training, limited resources and the absence of any policy deployment are important limitations for the development of lean projects. This justifies the absence of connection between firm performances and lean practices.

In addition to these studies, some of the papers analysed suggest that lean may have negative impacts on financial performance metrics. In other words, these studies in some way reject a positive relationship between lean practices and financial performance. For example, Meade et al. (2010) suggest that lean tends to generate a negative impact on turnover and profit margins in the short term, due to stocks being reduced, and remarks that traditional financial reporting methods may be inadequate to accurately reflect operational improvements through the early stages of a lean programme.

Finally, the results obtained by Galeazzo and Furlan (2018) showed that some lean bundles always have to be complemented by other lean bundles to improve financial metrics, because none of them can explain alone the firm's successful financial performance. According to the authors, JIT in combination with TQM or, instead, with TPM and HRM as complementary conditions is enough for achieving successful financial performance. In contrast, two combinations may produce limited results in terms of ROA; the first is characterized by a low level or lack of implementation of the TQM lean bundle, and the second combination complements the absence of HRM with the absence of TPM. They remark that with the limited implementation of the lean bundles, firms fail in obtaining good financial results.

\section{Discussion and paths for future research}

The aim of this research is to discuss whether firms that have applied lean principles and methods have improved their financial performance measures while analysing previous research on this topic. The main findings, inconsistencies and research gaps emerging from the SLR analysis can be examined as follows.

The study of the relationship between lean and financial metrics has experienced growing attention in recent years. Most of the papers have investigated the topic through a surveybased approach, which is an appropriate research method to understand whether there is a relationship between lean implementation and financial performance. Nevertheless, other research methodologies can be employed in order to complete the research results already obtained by a survey (Negrão et al., 2017; Sahoo, 2019). For example, by using qualitative research methods such as case studies, researchers may be able to better understand the nature and complexity of the complete phenomenon under analysis and to develop in-depth investigations in different contexts (Yin, 1994). Furthermore, qualitative studies can be used to empirically identify linkages between variables (lean practices and financial metrics) and to provide practical tools for professionals dealing with these issues in their work practice (Voss et al., 2002).

As regards the most analysed lean practices, the literature review carried out in this paper highlighted the importance of JIT and TQM bundles. In parallel, financial performance indicators such as ROI, sales growth rate, sales, ROA, net profit, profitability, profit margin and ROS seem to be the most measured. These results are in line with the analysis of the 
relevant literature developed by Hofer et al. (2012), who suggest that the JIT bundle is one of the most typically used by researchers in this area and remark that the JIT concept is part but not synonymous of lean production. Additionally, the same authors also acknowledge ROA and ROI as some of the most used financial performance metrics in previous research. Thus, other practices corresponding to the HRM bundle and to a lesser extent the TPM bundle, which have received less attention in the literature, should be prioritized in future analyses. These studies can be complemented with other financial performance measures that can broaden the spectrum of the analysis of the impact of lean on financial performance. Furthermore, a significant emphasis on financial outcomes is needed as more and more manufacturing firms reach higher lean maturity levels and are competing in similar conditions (e.g. lower production costs, superior responsiveness, higher quality levels and similar technologies) (Inman et al., 2011).

Regarding the time spans of research considered in the literature, most of the papers did not evaluate the implementation of lean practices during a specific time frame. In contrast, more than half of the studies considered different time spans ranging from 1 to 5 years to observe the financial performance variation of companies. The authors who do not consider a time interval for their analyses, acknowledge the cross-sectional nature of their studies as a limitation and suggest the development of longitudinal studies in order to gain more insights (Sahoo and Yadav, 2018; Shrafat and Ismail, 2019) and analyse causal factors (Negrão et al., 2019; Sahoo, 2019). In this sense, it is important to understand that the lean transformation process usually lasts more than a year since it represents a strategic-changing activity (Saad et al., 2006). Moreover, lean benefits are visible only in the medium/long term, while investments in implementation, which should worsen financial results, are recorded in the short term (Negrão et al., 2017). In brief, short time spans of research when studying the effects of lean on performance may lead to less accurate results that may not be generalizable. As stated by Voss et al. (2002), the longer the period over which a phenomenon is studied, the greater the opportunity to observe the sequential relationships of events. Hence, longitudinal studies represent a relevant research opportunity for scholars aiming to understand the nature and the evolution of the effects of lean on financial performance. This method allows the analysis of the evolution of financial performance metrics over time as firms achieve lean maturity.

The main results of this literature review suggest that lean initiatives could lead to an enhancement of financial performance measures according to various authors. More specifically, JIT (e.g. flow production, pull/Kanban, setup time reduction, cellular layouts) and TQM (e.g. customer involvement, statistical process control, supplier development, 5S) bundles seem to include the most impactful practices on financial measures such as sales and profit. These results are in line with previous findings that suggest that JIT practices enhance firms' profitability (Callen et al., 2000; Fullerton and McWatters, 2001) and that companies implementing quality improvement practices (TQM) will outperform competitors in terms of financial performance (Eriksson and Hansson, 2003; Fullerton and Wempe, 2009). In addition, the HRM and TPM lean bundles did not present a high number of publications relating them to financial performance goals. The literature demonstrates that these lean practices may not negatively affect financial performance (Negrão et al., 2019; Sahoo, 2019; Yang et al., 2011). Nevertheless, practices from both dimensions are increasingly being included in firms' lean implementation strategies since their deployment influences other practices. For instance, HRM practices have proven to be decisive due to their mediating role between soft and hard lean practices (Sahoo, 2019). Similarly, TPM practices are crucial for achieving continuous flow production, equipment effectiveness and workplace improvement (Galeazzo and Furlan, 2018). Thus, it might be interesting to obtain further empirical evidence about which HRM and TPM practices best improve financial performance metrics in lean contexts. 
JMTM 32,9

116

On the other hand, there are some existing divergences between lean and financial performance that have been already been acknowledged in the literature. Various authors suggest that lean practices no longer provide a competitive advantage as it is a highly spread strategy among competitors in sectors such as the motor industry. Moreover, approaches like agile manufacturing are recommended in some studies. According to diverse authors, agile firms consider external competitive factors and may incur in lower costs of implementation (Ghobakhloo and Azar, 2018; Yusuf and Adeleye, 2002). The lean and agile approaches do not have to be mutually exclusive strategies in today's dynamic environments and many businesses are already considering the amalgamation of both strategies. Other studies suggest that lean practices' implementation must be done holistically in order to succeed (Nawanir et al., 2013; Sahoo and Yadav, 2018) since there is a complementarity between bundles that will lead to better financial performance than a separated implementation or an execution of single practices. Galeazzo and Furlan (2018) suggest that some specific lean practices' combinations may produce lower results. There is scope for future research adopting a more holistic approach and discerning the multifaceted concept of lean. Still, future studies must consider lean practices from all dimensions to observe the complementarities and the joint effect of the whole lean practices implemented by manufacturers. Besides, the study of different combinations of lean practices for improving financial metrics is beyond the scope of this research and still requires further research in the future.

Finally, Meade et al. (2010) propose that lean tends to generate negative impacts on turnover and profit margins in the short term, and they remark the importance of financial reporting methods. Moreover, Bevilacqua et al. (2017a) highlight that the lack of systematic and sustainable approaches justifies the absence of connection between firm performances and lean practices. Thus, evidence suggests that lean manufacturing is not a quick remedy to financial issues (Galeazzo and Furlan, 2018). Table 3 presents eleven research questions that can guide future research paths in four research streams.

\section{Research questions}

Lean practices and financial performance measures in the literature (Sections 3.2.1 and 3.2.2)

(1) What HRM practices can impact financial performance metrics in lean production contexts?

(2) What TPM practices can impact financial performance metrics in lean production contexts?

(3) What financial measures best reflect the effects of lean production on firms' financial performance?

Lean implementation and financial performance over time (Section 3.2.3)

(1) How do financial performance measures evolve over time as lean maturity is achieved?

(2) What pattern do financial performance measures follow throughout the period of lean implementation?

(3) From what year after the implementation of lean strategies the effects on financial metrics are generally tangible?

Positive effects of lean practices on financial performance (Section 4.1)

(1) What combination of lean practices (JIT, TQM, TPM and HRM) most significantly improves financial performance?

(2) What HRM practices contribute to the improvement of financial performance metrics in lean production contexts?

(3) What TPM practices contribute to the improvement of financial performance metrics in lean production contexts?

Table 3.

Research questions to guide further research
Other effects of lean practices on financial performance (Section 4.2)

(1) What combination of lean practices (JIT, TQM, TPM and HRM) worsens financial performance the most?

(2) What financial control and reporting methods are more adequate to monitor the effect of lean practices on financial metrics? 


\section{Conclusions, limitations and contributions}

This article contributes to the lean body of knowledge by presenting a systematic review of the existing literature that considers the relationship between the implementation of lean practices and financial performance measures. The research findings and discussion provide new insights for scholars and contribute to the definition of clearer paths for further research.

By suggesting the utilization of research methods such as qualitative studies, long-term analyses and highlighting both lean practices and financial measures that need further investigation, this paper provides a relevant contribution for academics in the field. This paper also confirms that despite the great number of studies analysing the effects of lean on performance, only a small part of the literature addresses properly the study of the effects of lean practices on financial performance measures. This article differs from other literature review studies by developing a systematic approach to select papers that empirically analyse the effects of lean on financial performance indicators. The research methodology excludes papers utilizing combined paradigms (lean six sigma, lean-green or lean supply chain) or only focusing on operational performance measures. Furthermore, this study identifies and structures the results already obtained by previous empirical research to guide future empirical studies.

Additionally, there are several managerial implications considering best practices in the employment of lean production. Research findings may encourage firms, not entirely committed with the lean philosophy, to consider lean for achieving better financial results. Moreover, the results derived from the present research can provide managers with a general overview of the effects of lean practices on financial performance so they can develop deeper and richer knowledge on this topic. This research also encourages them, and hence their organizations, to implement lean practices in a coherent, sustained and holistic manner while measuring the impact of lean on financial performance indicators. This article may also be useful to understand the sequence of application of the practices to obtain specific financial outcomes. The study highlights which techniques could contribute to improve specific financial measures within a lean transformation context. In this regard, as suggested by Fullerton et al. (2014), companies may need to adapt their financial and accounting control systems to align them with lean manufacturing initiatives. This may lead to an increasing interaction between operations and accounting functions (Maskell et al., 2011).

On the other hand, this research has encountered some limitations that need to be acknowledged. Two relevant papers were not included in the initial paper selection sample since they did not meet the searching criteria. To avoid missing any other important articles, a systematic approach was adopted and a reference checking approach was used. Furthermore, the authors used different labels for both practices and indicators to carry out their studies. This limitation was overcome by grouping lean practices and financial measures with the same scope, respectively, in bundles and generic names. Additionally, the results from this study need to be contextualized since each paper under investigation considered different types of analysis, and, moreover, each study encompassed firms with very specific characteristics. In other words, the cause-effect relationships between the use of a technique and the expected result on a specific financial performance metric also depend on the contextual conditions that are internal but also external to organizations (Dieste et al., 2020; Panizzolo, 1998). Moreover, lean practices work together as a system and may have different configurations that could explain successful (or unsuccessful) financial performance (Galeazzo and Furlan, 2018).

Concluding, financial performance has always been one of the strategic imperatives for businesses and generally good results are connected to operational efficiency. Lean manufacturing practices have demonstrated in both practice and research that they can produce a relevant contribution to financial performance enhancement. Nevertheless, lean practices need to be implemented with coherence and holistically to support
Lean and financial performance: a review 
JMTM 32,9

complementarities and should be assisted by an appropriate and sustained performance measurement system. Finally, lean production must be treated as a strategic activity whose effects are visible in the long run to achieve the best results.

\section{References}

Abdel-Maksoud, A., Dugdale, D. and Luther, R. (2005), "Non-financial performance measurement in manufacturing companies", The British Accounting Review, Elsevier, Vol. 37 No. 3, pp. 261-297.

Bevilacqua, M., Ciarapica, F.E. and De Sanctis, I. (2017a), "Lean practices implementation and their relationships with operational responsiveness and company performance: an Italian study", International Journal of Production Research, Taylor \& Francis, Vol. 55 No. 3, pp. 769-794.

Bevilacqua, M., Ciarapica, F.E. and De Sanctis, I. (2017b), "Relationships between Italian companies' operational characteristics and business growth in high and low lean performers", Journal of Manufacturing Technology Management, Emerald Publishing, Vol. 28 No. 2, pp. 250-274.

Bhasin, S. (2012), "Performance of Lean in large organisations", Journal of Manufacturing Systems, The Society of Manufacturing Engineers, Vol. 31 No. 3, pp. 349-357.

Buchanan, D. and Bryman, A. (2009), The Sage Handbook of Organizational Research Methods, Sage Publications Ltd, London.

Callen, J.L., Fader, C. and Krinsky, I. (2000), "Just-in-time: a cross-sectional plant analysis", International Journal of Production Economics, Elsevier, Vol. 63 No. 3, pp. 277-301.

Chavez, R., Gimenez, C., Fynes, B., Wiengarten, F. and Yu, W. (2013), "Internal lean practices and operational performance", International Journal of Operations and Production Management, Emerald Group Publishing, Vol. 33 No. 5, pp. 562-588.

Chavez, R., Yu, W., Jacobs, M., Fynes, B., Wiengarten, F. and Lecuna, A. (2015), "Internal lean practices and performance: the role of technological turbulence", International Journal of Production Economics, Elsevier, Vol. 160, pp. 157-171.

Cua, K.O., McKone, K.E. and Schroeder, R.G. (2001), "Relationships between implementation of TQM, JIT, and TPM and manufacturing performance", Journal of Operations Management, Elsevier, Vol. 19 No. 6, pp. 675-694.

Demeter, K. and Matyusz, Z. (2011), "The impact of lean practices on inventory turnover", International Journal of Production Economics, Elsevier, Vol. 133 No. 1, pp. 154-163.

Dieste, M., Panizzolo, R., Garza-Reyes, J.A. and Anosike, A. (2019), "The relationship between lean and environmental performance: practices and measures", Journal of Cleaner Production, Vol. 224, pp. 120-131.

Dieste, M., Panizzolo, R. and Garza-Reyes, J.A. (2020), "Evaluating the impact of lean practices on environmental performance: evidences from five manufacturing companies", Production Planning and Control, Vol. 31 No. 9, pp. 739-756.

Eriksson, H. and Hansson, J. (2003), "The impact of TQM on financial performance", Measuring Business Excellence, Emerald Group Publishing, Vol. 7 No. 1, pp. 36-50.

Fink, A. (2005), Conducting Research Literature Reviews: From the Internet to Paper, Sage publications, Thousand Oaks.

Forrester, P.L., Soriano-Meier, H. and Garza-Reyes, J.A. (2010), "Lean production, market share and value creation in the agricultural machinery sector in Brazil", Journal of Manufacturing Technology Management, Vol. 21 No. 7, pp. 853-871.

Fullerton, R.R. and McWatters, C.S. (2001), "The production performance benefits from JIT implementation”, Journal of Operations Management, Elsevier, Vol. 19 No. 1, pp. 81-96.

Fullerton, R.R. and Wempe, W.F. (2009), "Lean manufacturing, non-financial performance measures, and financial performance", International Journal of Operations and Production Management, Vol. 29 No. 3, pp. 214-240. 
Fullerton, R.R., Kennedy, F.A. and Widener, S.K. (2014), "Lean manufacturing and firm performance: the incremental contribution of lean management accounting practices", Journal of Operations Management, Elsevier B.V., Vol. 32 Nos 7-8, pp. 414-428.

Galeazzo, A. (2019), "Degree of leanness and lean maturity: exploring the effects on financial performance", Total Quality Management and Business Excellence, Taylor \& Francis, pp. 1-19.

Galeazzo, A. and Furlan, A. (2018), "Lean bundles and configurations: a fsQCA approach", International Journal of Operations and Production Management, Emerald Publishing, Vol. 38 No. 2, pp. 513-533.

Ghobakhloo, M. and Azar, A. (2018), "Business excellence via advanced manufacturing technology and lean-agile manufacturing", Journal of Manufacturing Technology Management, Emerald Publishing, Vol. 29 No. 1, pp. 2-24.

Hofer, C., Eroglu, C. and Hofer, A.R. (2012), "The effect of lean production on financial performance: the mediating role of inventory leanness", International Journal of Production Economics, Elsevier, Vol. 138 No. 2, pp. 242-253.

Inman, R.A., Sale, R.S., Green, K.W. Jr and Whitten, D. (2011), "Agile manufacturing: relation to JIT, operational performance and firm performance", Journal of Operations Management, Elsevier, Vol. 29 No. 4, pp. 343-355.

Lewis, M.A. (2000), "Lean production and sustainable competitive advantage", International Journal of Operations and Production Management, Emerald Group Publishing, Vol. 20 No. 8, pp. 959-978.

Liker, J.K. (2004), The Toyota Way, McGraw-Hill, New York.

Losonci, D. and Demeter, K. (2013), "Lean production and business performance: international empirical results", Competitiveness Review, Vol. 23 No. 3, pp. 218-233.

Maskell, B.H., Baggaley, B. and Grasso, L. (2011), Practical Lean Accounting: A Proven System for Measuring and Managing the Lean Enterprise, CRC Press, Boca Raton.

Meade, D.J., Kumar, S. and White, B. (2010), "Analysing the impact of the implementation of lean manufacturing strategies on profitability", Journal of the Operational Research Society, Taylor \& Francis, Vol. 61 No. 5, pp. 858-871.

Nawanir, G., Lim, K.T. and Othman, S.N. (2013), "Impact of lean practices on operations performance and business performance: some evidence from Indonesian manufacturing companies", Journal of Manufacturing Technology Management, Emerald Group Publishing, Vol. 24 No. 7, pp. 1019-1050.

Nawanir, G., Lim, K.T. and Othman, S.N. (2016), "Lean manufacturing practices in Indonesian manufacturing firms: are there business performance effects?", International Journal of Lean Six Sigma, Vol. 7 No. 2, pp. 149-170.

Negrão, L.L.L., Godinho Filho, M. and Marodin, G. (2017), "Lean practices and their effect on performance: a literature review”, Production Planning and Control, Taylor \& Francis, Vol. 28 No. 1, pp. 33-56.

Negrão, L.L.L., Lopes de Sousa Jabbour, A.B., Latan, H., Godinho Filho, M., Chiappetta Jabbour, C.J. and Ganga, G.M.D. (2019), "Lean manufacturing and business performance: testing the S-curve theory”, Production Planning and Control, Taylor \& Francis, Vol. 31 No. 10, pp. 771-785.

Ohno, T. (1988), Toyota Production System: Beyond Large-Scale Production, Productivity Press, Portland.

Panizzolo, R. (1998), "Applying the lessons learned from 27 lean manufacturers: the relevance of relationships management”, International Journal of Production Economics, Vol. 55 No. 3, pp. 223-240.

Saad, S., Perera, T., Achanga, P., Shehab, E., Roy, R. and Nelder, G. (2006), "Critical success factors for lean implementation within SMEs", Journal of Manufacturing Technology Management, Emerald Group Publishing, Vol. 17 No. 4, pp. 460-471. 
JMTM 32,9

Sahoo, S. (2019), "Lean manufacturing practices and performance: the role of social and technical factors", International Journal of Quality and Reliability Management, Emerald Publishing, Vol. 37 No. 5, pp. 732-754.

Sahoo, S. and Yadav, S. (2018), "Lean production practices and bundles: a comparative analysis", International Journal of Lean Six Sigma, Emerald Publishing, Vol. 9 No. 3, pp. 374-398.

Saunders, M., Lewis, P. and Thornhill, A. (2009), Research Methods for Business Students, Pearson education, Essex.

Shah, R. and Ward, P.T. (2003), "Lean manufacturing: context, practice bundles, and performance", Journal of Operations Management, Elsevier, Vol. 21 No. 2, pp. 129-149.

Shrafat, F.D. and Ismail, M. (2019), "Structural equation modeling of lean manufacturing practices in a developing country context", Journal of Manufacturing Technology Management, Emerald Publishing, Vol. 30 No. 1, pp. 122-145.

Tranfield, D., Denyer, D. and Smart, P. (2003), "Towards a methodology for developing evidenceinformed management knowledge by means of systematic review", British Journal of Management, Wiley Online Library, Vol. 14 No. 3, pp. 207-222.

Voss, C., Tsikriktsis, N. and Frohlich, M. (2002), "Case research in operations management", International Journal of Operations and Production Management, Vol. 22 No. 2, pp. 195-219.

Womack, J.P. and Jones, D.T. (1996), Lean Thinking-Banish Waste and Create Wealth in Your Corporation, Simon \& Schuster, New York.

Womack, J.P., Jones, D.T. and Roos, D. (1990), The Machine that Changed the World, Simon \& Schuster, New York.

Yang, M.G.M., Hong, P. and Modi, S.B. (2011), "Impact of lean manufacturing and environmental management on business performance: an empirical study of manufacturing firms", International Journal of Production Economics, Elsevier, Vol. 129 No. 2, pp. 251-261.

Yin, R.K. (1994), Case Study Research and Applications: Design and Methods, Sage publications, Thousand Oaks.

Yusuf, Y.Y. and Adeleye, E.O. (2002), "A comparative study of lean and agile manufacturing with a related survey of current practices in the UK", International Journal of Production Research, Taylor \& Francis, Vol. 40 No. 17, pp. 4545-4562.

Zhu, X. and Lin, Y. (2017), “Does lean manufacturing improve firm value?”, Journal of Manufacturing Technology Management, Vol. 28 No. 4, pp. 422-437.

\section{Corresponding author}

Marcos Dieste can be contacted at: marcos.dieste@unipd.it 
Appendix

\begin{tabular}{|c|c|c|c|c|}
\hline Author(s) & $\begin{array}{l}\text { Publication } \\
\text { year }\end{array}$ & Title & Methodology & $\begin{array}{l}\text { performance: } \\
\text { a review }\end{array}$ \\
\hline Galeazzo & 2019 & $\begin{array}{l}\text { Degree of leanness and lean maturity: exploring the } \\
\text { effects on financial performance }\end{array}$ & Survey & \\
\hline Negrão et al. & 2019 & $\begin{array}{l}\text { Lean manufacturing and business performance: } \\
\text { testing the S-curve theory }\end{array}$ & Survey & 121 \\
\hline Sahoo & 2019 & $\begin{array}{l}\text { Lean manufacturing practices and performance: the } \\
\text { role of social and technical factors }\end{array}$ & Survey & \\
\hline $\begin{array}{l}\text { Shrafat and } \\
\text { Ismail }\end{array}$ & 2019 & $\begin{array}{l}\text { Structural equation modeling of lean manufacturing } \\
\text { practices in a developing country context }\end{array}$ & Survey & \\
\hline $\begin{array}{l}\text { Galeazzo and } \\
\text { Furlan }\end{array}$ & 2018 & Lean bundles and configurations: a fsQCA approach & Survey & \\
\hline $\begin{array}{l}\text { Ghobakhloo and } \\
\text { Azar }\end{array}$ & 2018 & $\begin{array}{l}\text { Business excellence via advanced manufacturing } \\
\text { technology and lean-agile manufacturing }\end{array}$ & Survey & \\
\hline $\begin{array}{l}\text { Sahoo and } \\
\text { Yadav }\end{array}$ & 2018 & $\begin{array}{l}\text { Lean production practices and bundles: a comparative } \\
\text { analysis }\end{array}$ & Survey & \\
\hline Bevilacqua et al. & $2017 \mathrm{a}$ & $\begin{array}{l}\text { Lean practices implementation and their relationships } \\
\text { with operational responsiveness and company } \\
\text { performance: an Italian study }\end{array}$ & Survey & \\
\hline Bevilacqua et al. & $2017 \mathrm{~b}$ & $\begin{array}{l}\text { Relationships between Italian companies' operational } \\
\text { characteristics and business growth in high and low } \\
\text { lean performers }\end{array}$ & Survey & \\
\hline Negrão et al. & 2017 & $\begin{array}{l}\text { Lean practices and their effect on performance: } \\
\text { a literature review }\end{array}$ & $\begin{array}{l}\text { Literature } \\
\text { review }\end{array}$ & \\
\hline Zhu and Lin & 2017 & Does lean manufacturing improve firm value? & $\begin{array}{l}\text { Research } \\
\text { database }\end{array}$ & \\
\hline Nawanir et al. & 2016 & $\begin{array}{l}\text { Lean manufacturing practices in Indonesian } \\
\text { manufacturing firms: Are there business performance } \\
\text { effects? }\end{array}$ & Survey & \\
\hline Chavez et al. & 2015 & $\begin{array}{l}\text { Internal lean practices and performance: The role of } \\
\text { technological turbulence }\end{array}$ & Survey & \\
\hline Fullerton et al. & 2014 & $\begin{array}{l}\text { Lean manufacturing and firm performance: The } \\
\text { incremental contribution of lean management } \\
\text { accounting practices }\end{array}$ & Survey & \\
\hline $\begin{array}{l}\text { Losonci and } \\
\text { Demeter }\end{array}$ & 2013 & $\begin{array}{l}\text { Lean production and business performance: } \\
\text { international empirical results }\end{array}$ & $\begin{array}{l}\text { Research } \\
\text { database }\end{array}$ & \\
\hline Nawanir et al. & 2013 & $\begin{array}{l}\text { Impact of lean practices on operations performance } \\
\text { and business performance: some evidence from } \\
\text { Indonesian manufacturing companies }\end{array}$ & Survey & \\
\hline Bhasin & 2012 & Performance of lean in large organisations & Survey & \\
\hline Hofer et al. & 2012 & $\begin{array}{l}\text { The effect of lean production on financial performance: } \\
\text { The mediating role of inventory leanness }\end{array}$ & Survey & \\
\hline Yang et al. & 2011 & $\begin{array}{l}\text { Impact of lean manufacturing and environmental } \\
\text { management on business performance: An empirical } \\
\text { study of manufacturing firms }\end{array}$ & $\begin{array}{l}\text { Research } \\
\text { database }\end{array}$ & \\
\hline Forrester et al. & 2010 & $\begin{array}{l}\text { Lean production, market share and value creation in } \\
\text { the agricultural machinery sector in Brazil }\end{array}$ & Survey & \\
\hline Meade et al. & 2010 & $\begin{array}{l}\text { Analysing the impact of the implementation of lean } \\
\text { manufacturing strategies on profitability }\end{array}$ & Simulation & \\
\hline $\begin{array}{l}\text { Fullerton and } \\
\text { Wempe }\end{array}$ & 2009 & $\begin{array}{l}\text { Lean manufacturing, non-financial performance } \\
\text { measures, and financial performance }\end{array}$ & Survey & \\
\hline $\begin{array}{l}\text { Yusuf and } \\
\text { Adeleye }\end{array}$ & 2002 & $\begin{array}{l}\text { A comparative study of lean and agile manufacturing } \\
\text { with a related survey of current practices in the UK }\end{array}$ & Survey & \\
\hline Lewis & 2000 & $\begin{array}{l}\text { Lean production and sustainable competitive } \\
\text { advantage }\end{array}$ & Case study & $\begin{array}{r}\text { Table A1. } \\
\text { Articles included in the } \\
\text { literature review }\end{array}$ \\
\hline
\end{tabular}

